\title{
EFFECT OF METHOXYFLURANE ANAESTHESIA AND SURGERY ON HUMAN GROWTH HORMONE AND INSULIN LEVELS IN PLASMA
}

\author{
Tsutomu Oyama, M.D., AND T. TaKazaWA, M.D."
}

THE METABOLIC CHANGES that occur during stress have been attributed primarily to increased activity of the sympathetic nervous system, and to an increase in the secretion of ACTH and the corticosteroids. A decrease in utilization of infused glucose and a glucose intolerance have been reported to occur with ether. ${ }^{1,2}$ The possibility that ether anaesthesia may interfere with the action of insulin has been considered by Henneman and Vandam, ${ }^{3}$ but this has been questioned by Greene. ${ }^{4}$

Human growth hormone (HGF) of the anterior pituitary gland is known to be related not only to growth but also to the metabolism of glucose, fat, and protein, ${ }^{5,6}$ Large rises in plasma HGH concentration have recently been reported during surgical stress. ${ }^{711}$ Furthermore, participation of $\mathrm{HGH}$ in the metabolic responses to acute stress has been suggested. ${ }^{7}$ The present study was undertaken to explore the effects of methoxyflurane anaesthesia alone on the carbohydrate and fat metabolism by determining plasma growth hormone, insulin, blood glucose (BG), free fatty acids (FFA), and cortisol, and to compare this with effects of anaesthesia plus surgery.

\section{Materuals and Methods}

Twenty male patients, ranging in age from 15 to 65 years, were the subjects of the study. All patients underwent elective operations, and no patient had hepatic, renal, or endocrinological disease, or a history of steroid therapy. The type of operation and ages of the patients are shown in Table I. They did not receive food or water for at least 12 hours prior to induction of anaesthesia, and no intravenous fluid was infused during this period. The average operating time was three hours and ten minutes; mean anaesthetic time was four hours and forty minutes.

Each patient was premedicated with pentobarbital $50-100 \mathrm{mg}$ orally one and one-half hours prior to the induction of anaesthesia. Atropine $0.5 \mathrm{mg}$ and meperidine $35 \mathrm{mg}$ were injected intramuscularly one and one-quarter hours before the induction of anaesthesia. Methoxyflurane anaesthesia was induced with inspired concentrations between 0.6 and 1.2 per cent from a Pentec vaporizer, combined with $\mathrm{N}_{2} \mathrm{O}(2 \mathrm{~L} / \mathrm{min})$ and $\mathrm{O}_{2}(2 \mathrm{~L} / \mathrm{min})$ under mask at 8:00-8:30 AM. After endotracheal intubation following injection of $40 \mathrm{mg}$ of succinylcholine chloride, anaesthesia was maintained with methoxyflurane, $\mathrm{N}_{2} \mathrm{O}(2 \mathrm{~L} / \mathrm{min})$ and $\mathrm{O}_{2}$ ( $2 \mathrm{~L} / \mathrm{min})$.

Controlled or assisted ventilation was carried on throughout the procedure.

- Department of Anaesthesiology, Hirosaki University School of Medicine, Hirosaki, AomariKen, Japan. 
TABLE I

Patients and Operations Studied

\begin{tabular}{lllll}
\hline \hline No. & Name & Age & Wt. kg. & \multicolumn{1}{c}{ Operation } \\
\hline 1 & K.O. & 65 & 48.5 & oesophagectomy \\
2 & Y.T. & 44 & 48.0 & cystectomy \\
3 & N.Y. & 44 & 65.0 & gastrectomy \\
4 & T.F. & 35 & 60.0 & ampt. of left middle finger \\
5 & I.N. & 48 & 47.0 & gastrectomy \\
6 & T.Y. & 36 & 58.0 & exploratory laparotomy \\
7 & Y.I. & 59 & 53.0 & cholecystectomy \\
8 & S.N. & 24 & 58.5 & exploration of right elbow joint \\
9 & T.T. & 64 & 48.5 & gastrectomy \\
10 & K.T. & 58 & 69.5 & gastrectomy \\
11 & T.K. & 24 & 58.0 & fxation of right hip joint \\
12 & T.T. & 64 & 56.0 & gastrectomy \\
13 & T.A. & 52 & 63.0 & gastrectomy \\
14 & M.K. & 15 & 35.0 & osteotomy of left thigh bone \\
15 & K.M. & 15 & 43.0 & osteosynthesis of right humerus \\
16 & Z.S. & 27 & 60.0 & fixation of left shoulder joint \\
17 & T.O. & 54 & 58.0 & oesophagectomy \\
18 & N.N. & 43 & 48.0 & cholecystectomy \\
19 & Y.F. & 22 & 58.0 & plastic op. of right foot skin \\
20 & H.N. & 60 & 63.0 & plastic op. of tends of fingers \\
\hline
\end{tabular}

A moderate depth of anaesthesia was maintained by clinical judgment based on signs including blood pressure, pulse rate, and somatic reflexes in response to the surgical stimuli. In addition, occasional observation by EEG was made. Anaesthesia alone lasted for at least 45 minutes in each case. Normal saline $100-300 \mathrm{ml}$ was infused during the period of anaesthesia alone and until 15 minutes after the beginning of operation. Low molecular weight dextran $500 \mathrm{ml}$ was infused throughout the operation, and whole blood was transfused when blood loss exceeded $500 \mathrm{ml}$.

Eight blood samples were taken from each patient: one, a control sample, at 8:30 AM, immediately before induction of anaesthesia, three samples 15,30 , and 45 minutes after methoxyflurane anaesthesia, three samples 5-10, 30, and 60 minutes after the start of surgery, and one sample in the recovery room when the patient was fully awake. Five $\mathrm{ml}$ of venous blood was collected on each occasion in a heparinized syringe, rapidly transferred to a tube, then centrifuged within 30 minutes of collection. One $\mathrm{ml}$ of these plasma samples was kept at $-20^{\circ} \mathrm{C}$, and thawed within one month, just prior to radioimmunoassay for growth hormone and insulin. One $\mathrm{ml}$ of plasma was kept at $4^{\circ} \mathrm{C}$ for analysis of cortisol and FFA (free fatty acids = nonesterified fatty acids [NEFA]), and $0.2 \mathrm{ml}$ of blood was used to measure blood glucose.

Determination of plasma growth hormone ( $\mathrm{HGH}$ ) was done according to the method of Schalch and Parker. ${ }^{7}$ The analysis of plasma insulin was made after the method of Morgan and Lazarow. ${ }^{12}$ These double antibody methods were based on the principle of radioimmunoassay, utilizing $\mathrm{I}^{125}$, which is the competitive inhibition, by unlabelled hormone, of the binding of the labelled hormone to its specific antibody. Duplicate determinations were made for all specimens and the mean values were taken. The recovery rate for HGH was 98 per cent and for insulin 94 per cent by our method, which indicates reliable analysis. 
The plasma cortisol concentration was measured by Murphy's radiostereoassay ${ }^{13}$ with a Beckman liquid scintillation counter, using $\mathrm{H}^{3}$-corticosterone. The recovery rate of cortisol by our method was 95 per cent and the duplicate error of the same sample was $\pm 1.5 \mu \mathrm{g}$ per $100 \mathrm{ml}$ of plasma. The blood glucose (BG) was measured by the method of Somogyi, ${ }^{14}$ and plasma FFA was determined by the colorimetric method of Dumcombe. ${ }^{15}$

\section{RESULtS}

\section{Plasma growth hormone}

Control plasma growth hormone ( $\mathrm{HGH}$ ) level in 20 patients after receiving premedication and immediately before induction of anaesthesia was $1.4 \pm 0.5$ $\mathrm{m} \mu \mathrm{g} / \mathrm{ml}$, which was within normal limits (less than $5.0 \mathrm{~m} \mu \mathrm{g} / \mathrm{ml}$ ). The mean presurgical concentration of $\mathrm{HGH}$ in plasma after 15 minutes of methoxyllurane anaesthesia in 20 patients was increased to $2.1 \pm 0.6 \mathrm{~m} \mu \mathrm{g} / \mathrm{ml}$. It further increased significantly to $4.6 \pm 1.2 \mathrm{~m} \mu \mathrm{g} / \mathrm{ml}(p<0.03)$ and $6.0 \pm 1.6 \mathrm{~m} \mu \mathrm{g} / \mathrm{ml}(p<0.02)$ 30 minutes and 45 minutes after the induction of anaesthesia respectively.

Plasma levels of $\mathrm{HGH}$ decreased slightly to $5.5 \pm 1.3 \mathrm{~m} \mu \mathrm{g} / \mathrm{ml}$ within 5 to 10 minutes of the skin incision, but they significantly rose to $7.7 \pm 1.5 \mathrm{~m} \mu \mathrm{g} / \mathrm{ml}$ $(p<0.005)$ and $8.0 \pm 1.5 \mathrm{~m} \mu \mathrm{g} / \mathrm{ml}(p<0.001) 30$ minutes and one hour after the start of surgery respectively, as illustrated in Table II and Figure 1. Levels decreased slightly from the peak value but still remained elevated $(6.5 \pm 1.4$

TABLE II

Plasma hgh Levels during Methoxyflurane Anaesthesia and Surgery $(\mathrm{m} \mu \mathrm{g} / \mathrm{ml}$ )

\begin{tabular}{|c|c|c|c|c|c|c|c|c|}
\hline \multirow[b]{2}{*}{ Subjects } & \multicolumn{8}{|c|}{ Time (min) } \\
\hline & preind. & anaes. 15 & 30 & 45 & op. 10 & 30 & 60 & recovery \\
\hline 1 & 1.0 & 5.7 & 12.5 & 12.5 & 6.3 & 10.6 & 8.0 & 4.0 \\
\hline 2 & 0.2 & 4.4 & 16.5 & 22.0 & 17.4 & 12.8 & 13.0 & 5.4 \\
\hline 3 & 0.2 & 0.4 & 1.2 & 1.5 & 2.8 & 1.6 & 4.0 & 1.2 \\
\hline 4 & 0.2 & 0.2 & 4.6 & 8.6 & 9.6 & 8.4 & - & 8.8 \\
\hline 5 & 1.3 & 1.1 & 0.9 & 0.9 & 3.8 & 3.7 & 5.1 & $4 . \overline{5}$ \\
\hline 6 & 6.6 & 12.6 & 14.0 & 18.6 & 19.0 & 18.8 & - & 5.0 \\
\hline 7 & 1.0 & 0.7 & 9.4 & 9.7 & 11.0 & 19.9 & 15.1 & 2.8 \\
\hline 8 & 0.7 & 0.8 & 13.7 & 18.9 & 9.4 & 5.2 & 5.3 & 6.6 \\
\hline 9 & 1.0 & 1.0 & 1.3 & 5.3 & 5.9 & 4.8 & 7.8 & 1.4 \\
\hline 10 & 0.5 & 0.6 & 1.1 & 0.7 & 0.9 & - & 2.7 & 1.5 \\
\hline 11 & 1.4 & 1.0 & 3.2 & 1.7 & 1.1 & 8.2 & 18.8 & 15.4 \\
\hline 12 & 1.5 & 2.9 & - & 11.8 & 10.7 & 17.9 & 11.4 & 4.5 \\
\hline 13 & 0.8 & 1.0 & 1.2 & 1.3 & 1.9 & 15.2 & 15.3 & 5.4 \\
\hline 14 & 8.0 & 4.1 & 2.8 & 1.3 & 1.3 & 2.4 & 3.3 & 12.6 \\
\hline 15 & 0.9 & 1.4 & 0.6 & 0.2 & 0.8 & 1.7 & - & 11.1 \\
\hline 16 & 0.4 & 0.5 & 0.8 & 0.8 & 0.5 & 0.3 & 0.2 & 0.2 \\
\hline 17 & 0.7 & 0.9 & 1.1 & 0.8 & 1.2 & 5.6 & - & 6.5 \\
\hline 18 & 0.8 & 0.9 & 0.8 & 0.9 & 0.8 & 0.6 & 0.6 & 25.7 \\
\hline 19 & 0.3 & 0.6 & 0.3 & 0.6 & 0.5 & 0.3 & 0.5 & 1.0 \\
\hline 20 & 0.3 & 1.5 & 1.2 & 1.1 & - & - & 17.3 & - \\
\hline Mean & 1.4 & 2.1 & 4.6 & 6.0 & 5.5 & 7.7 & 8.0 & 6.5 \\
\hline \pm S.E. & 0.5 & 0.6 & 1.2 & 1.6 & 1.3 & 1.5 & 1.5 & 1.4 \\
\hline$p$ & & n.s.* & $<0.03 \dagger$ & $<0.02 \dagger$ & $<0.01 \dagger$ & $<0.005 \dagger$ & $<0.001 \dagger$ & $<0.005 \dagger$ \\
\hline
\end{tabular}

*Statistically not significant

†Statistically significant compared with preinduction. 


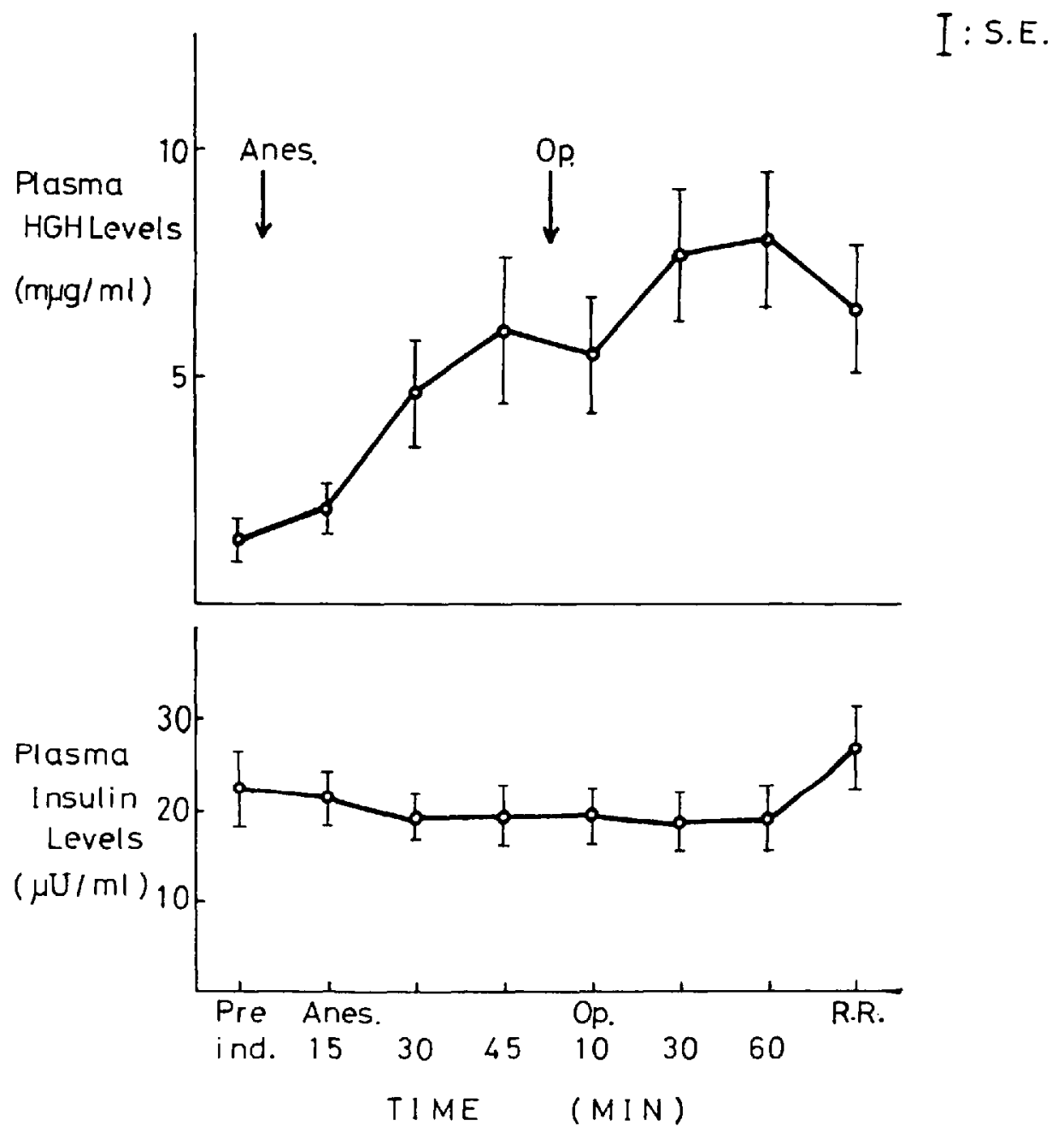

FIGUne 1. Plasma levels of HGH and insulin during methoxyflurane anaesthesia and surgery. $\mathrm{m} \mu \mathrm{g}[p<0.005])$ in the recovery room when the patient had recovered adequately.

\section{Plasma insulin}

The mean preanaesthetic control insulin level in plasma in 20 patients was $22.8 \pm 4.0 \mu \mathrm{U} / \mathrm{ml}$, which was within normal limits $(5-35 \mu \mathrm{U} / \mathrm{ml})$. The mean plasma insulin level 15 minutes after the induction of anaesthesia was $21.7 \pm 3.1$ $\mu \mathrm{v} / \mathrm{ml}$. It then decreased and varied from $18.9 \pm 3.1$ to $19.7 \pm 2.9 \mu \mathrm{v} / \mathrm{ml}$ during anaesthesia and surgery, which demonstrated no appreciable alteration, as shown in Table III and Figure 1.

\section{Plasma cortisol}

The mean control plasma cortisol level in 20 patients was $15.4 \pm 0.9 \mu \mathrm{g} / 100$ ml. After 15 minutes of methoxyflurane anaesthesia it was $17.4 \pm 0.9 \mu \mathrm{g}$, after 
TABLE III

Plasma Insulin Levels during Methoxyflurane Anaesthesia and Surgery ( $\mu \mathrm{U} / \mathrm{ml}$ )

\begin{tabular}{|c|c|c|c|c|c|c|c|c|}
\hline \multirow[b]{2}{*}{ Subjects } & \multicolumn{8}{|c|}{ Time (min) } \\
\hline & preind. & anaes. 15 & 30 & 45 & op. 10 & 30 & 60 & recovery \\
\hline 1 & 2.3 & 9.2 & 9.2 & 6.9 & 4.6 & 6.9 & 9.2 & 9.2 \\
\hline 2 & 4.6 & 23.0 & 23.0 & 9.2 & 23.0 & 32.2 & 23.0 & 36.8 \\
\hline 3 & 4.6 & 11.5 & 11.5 & 6.9 & 6.9 & 11.5 & 18.4 & 18.4 \\
\hline 4 & 11.5 & 11.5 & 23.0 & 23.0 & 4.6 & 11.5 & $\longrightarrow$ & 16.1 \\
\hline 5 & 18.4 & 16.1 & 9.2 & 9.2 & 11.5 & 4.6 & 13.8 & 23.0 \\
\hline 6 & 36.8 & 36.8 & 29.9 & 39.1 & 25.3 & 41.4 & - & 41.4 \\
\hline 7 & 20.7 & 18.4 & 34.5 & 18.4 & 23.0 & 20.9 & 16.1 & 46.0 \\
\hline 8 & 48.3 & 52.4 & 9.2 & 8.1 & 13.8 & 11.5 & 9.2 & 9.2 \\
\hline 9 & 11.5 & 29.9 & 18.4 & 25.3 & 18.4 & 34.5 & 25.3 & 27.6 \\
\hline 10 & 69.0 & 41.4 & 39.1 & 62.1 & 36.8 & - & 34.5 & 34.5 \\
\hline 11 & 46.0 & 18.4 & 32.2 & 36.8 & 52.9 & 41.4 & 46.0 & 75.9 \\
\hline 12 & 27.6 & 23.0 & - & 23.0 & 16.1 & 13.8 & 6.9 & 11.5 \\
\hline 13 & 34.5 & 50.6 & 27.6 & 36.8 & 29.9 & 41.4 & 34.5 & 43.7 \\
\hline 14 & 4.6 & 6.9 & 11.5 & 6.9 & 20.7 & 6.9 & 11.5 & 46.0 \\
\hline 1.5 & 16.1 & 9.2 & 4.6 & - & 13.8 & 6.9 & - & 13.8 \\
\hline 16 & 41.4 & 23.0 & 18.4 & 27.6 & 36.8 & 27.6 & 34.5 & 9.2 \\
\hline 17 & 27.6 & 11.5 & 4.6 & 11.5 & 13.8 & 13.8 & - & 6.9 \\
\hline 18 & 13.8 & 11.5 & 11.5 & 9.2 & 11.5 & 6.9 & 11.5 & 39.1 \\
\hline 19 & 6.9 & 25.3 & 39.1 & 4.6 & 11.5 & 6.9 & 16.1 & $6 . \overline{9}$ \\
\hline 20 & 9.2 & 4.6 & 9.2 & 4.6 & - & - & 4.6 & - \\
\hline Mean & 22.8 & 21.7 & 19.2 & 19.4 & 19.7 & 18.9 & 19.7 & 27.1 \\
\hline \pm s.E. & 4.0 & 3.1 & 2.6 & 3.4 & 2.8 & 3.1 & 2.9 & 4.2 \\
\hline$p$ & & $\mathrm{n} . \mathrm{s}^{*}$ & n.s.* & n.s.* & n.s.* & n.s. ${ }^{*}$ & ת.s. ${ }^{*}$ & n.s. ${ }^{*}$ \\
\hline
\end{tabular}

*Statistically not significant.

30 minutes $18.4 \pm 1.9 \mu \mathrm{g}$, and after 45 minutes $17.5 \pm 1.3 \mu \mathrm{g}$. These variations were not statistically significant from the control preanaesthetic level. However, the plasma cortisol level significantly increased to $19.3 \pm 1.6 \mu \mathrm{g} / 100 \mathrm{ml}(p<$ $0.05)$ within ten minutes of the skin incision. It increased significantly to $22.0 \pm$ $3.0 \mu \mathrm{g}(p<0.05)$ at 30 minutes and to $23.4 \pm 3.0 \mu \mathrm{g}(p<0.03)$ at one hour after the start of surgery. It rose to a peak level of $23.9 \pm 2.6 \mu \mathrm{g} / 100 \mathrm{ml}(p<$ 0.01 ) in the recovery room. (See Table IV and Fig. 2.)

\section{Blood glucose}

The mean control preanaesthetic blood glucose level in 20 patients was $99 \pm 7$ $\mathrm{mg} / 100 \mathrm{ml}$. It increased slightly to $102 \pm 7 \mathrm{mg}, 104 \pm 6 \mathrm{mg}$, and $108 \pm 8$ $\mathrm{mg} / 100 \mathrm{ml} \mathrm{15}, 30$, and 45 minutes respectively after the induction of anaesthesia. These values were not significantly different from the control level, as shown in Table $\mathrm{V}$ and Figure 2. The glucose level increased to $110 \pm 8 \mathrm{mg} / 100 \mathrm{ml}$ within ten minutes of the start of the operation, and it was significantly elevated to $123 \pm 8 \mathrm{mg}(p<0.03)$ at 30 minutes and $147 \pm 13 \mathrm{mg}(p<0.005)$ at one hour after the start of surgery. Blood glucose levels were highest in the recovery room ( $155 \pm 4 \mathrm{mg}[p<0.005]$ ).

\section{Plasma free fatty acids (FFA)}

The average control preanaesthetic FFA level in plasma in 20 patients was $30.7 \pm 3.8 \mathrm{mg} / 100 \mathrm{ml}$. It significantly increased $(p<0.05)$ to $144 \pm 17$ per cent 
TABLE IV

Plasma Cortisol Levels during Methoxyflurane Anaesthesia and Surgery $(\mu \mathrm{g} / 100 \mathrm{ml})$

\begin{tabular}{|c|c|c|c|c|c|c|c|c|}
\hline \multirow[b]{2}{*}{ Subjects } & \multicolumn{8}{|c|}{ Time (min) } \\
\hline & preind. & anaes. 15 & 30 & 45 & op. 10 & 30 & 60 & recovery \\
\hline 1 & 16.5 & 19.0 & 29.5 & 27.0 & 23.5 & 26.0 & 23.5 & 35.0 \\
\hline 2 & 20.0 & 20.0 & 17.0 & 20.0 & 24.0 & 36.0 & 33.0 & 35.0 \\
\hline 3 & 18.0 & 17.0 & 17.0 & 18.0 & 16.0 & 16.0 & - & 21.0 \\
\hline 4 & 17.0 & 21.5 & 11.0 & 17.0 & 20.0 & 41.0 & 39.0 & 33.0 \\
\hline 5 & 16.0 & 14.0 & 10.0 & 15.0 & 20.0 & 22.0 & - & 34.0 \\
\hline 6 & 15.5 & 15.0 & 11,0 & 15.0 & 19.5 & 11.5 & 11.0 & 12.0 \\
\hline 7 & 15.5 & 15.5 & 21.0 & 17.5 & 31.0 & 16.0 & 11.0 & 11.0 \\
\hline 8 & 16.0 & 15.0 & 16.0 & 17.0 & 12.0 & 10.5 & 20.0 & 24.5 \\
\hline 9 & 15.0 & 13.0 & 24.0 & 20.5 & 13.5 & - & 24.0 & 18.0 \\
\hline 10 & 11.0 & 22.5 & 27.5 & 17.5 & 18.0 & 24.0 & 30.0 & 20.0 \\
\hline 11 & 9.0 & 19.0 & 18.0 & 8.0 & 14.5 & 16.5 & 19.0 & 19.0 \\
\hline Mean & 15.4 & 17.4 & 18.4 & 17.5 & 19.3 & 22.0 & 23.4 & 23.9 \\
\hline $\pm S . E$. & 0.9 & 0.9 & 1.9 & 1.3 & 1.6 & 3.0 & 3.0 & 2.6 \\
\hline$p$ & & n.s.* & n.s.* & n.s.* & $<0.05 \dagger$ & $<0.05 \dagger$ & $<0.03 \dagger$ & $<0.01 \dagger$ \\
\hline
\end{tabular}

*Statistically not significant.

†Statistically significant compared with preinduction.

TABLE $V$

Blood Glucose Concentration during Methoxyflurane Anaesthesia and Surgery $(\mathrm{mg} / 100 \mathrm{ml})$

\begin{tabular}{|c|c|c|c|c|c|c|c|c|}
\hline \multirow[b]{2}{*}{ Subjects } & \multicolumn{8}{|c|}{ Time (min) } \\
\hline & preind. & anaes. 15 & 30 & 45 & op. 10 & 30 & 60 & recovery \\
\hline 1 & 88 & 78 & 106 & 112 & 104 & 144 & 184 & 256 \\
\hline 2 & 99 & 96 & 99 & 109 & 129 & 124 & 117 & 165 \\
\hline 3 & 65 & 77 & 82 & 68 & 72 & 97 & 123 & 216 \\
\hline 4 & 88 & 144 & 104 & 80 & 88 & 104 & - & 104 \\
\hline 5 & 96 & 108 & 88 & 134 & 118 & 132 & 126 & 126 \\
\hline 6 & 70 & 42 & 42 & 60 & 42 & 46 & - & 56 \\
\hline 7 & 135 & 117 & 125 & 154 & 140 & 142 & 148 & 160 \\
\hline 8 & 54 & 74 & 92 & 66 & 92 & 130 & 158 & 146 \\
\hline 9 & 116 & 112 & 92 & 196 & 208 & 208 & 258 & 324 \\
\hline 10 & 94 & 100 & 110 & 94 & 94 & - & 194 & 148 \\
\hline 11 & 100 & 106 & 88 & 100 & 116 & 112 & 112 & 128 \\
\hline 12 & 60 & 60 & - & 80 & 112 & 98 & 110 & 156 \\
\hline 13 & 96 & 62 & 80 & 74 & 80 & 114 & 76 & 118 \\
\hline 14 & 168 & 148 & 122 & 110 & 110 & 184 & 244 & 244 \\
\hline 15 & 122 & 142 & 140 & 116 & 130 & 130 & - & 136 \\
\hline 16 & 114 & 128 & 128 & 118 & 118 & 118 & 132 & 118 \\
\hline 17 & 64 & 94 & 116 & 106 & 106 & 132 & - & 110 \\
\hline 18 & 137 & 142 & 137 & 174 & 158 & 106 & 100 & 142 \\
\hline 19 & 58 & 68 & 84 & 72 & 76 & 90 & 100 & 90 \\
\hline 20 & 152 & 143 & 134 & 130 & - & - & 180 & - \\
\hline Mean & 99 & 102 & 104 & 108 & 110 & 123 & 147 & 155 \\
\hline S.E. & 7 & 7 & 6 & 8 & 8 & 8 & 13 & 14 \\
\hline$p$ & & n.s.* & n.s.* & n.s. ${ }^{*}$ & $\pi . s,{ }^{*}$ & $<0.03 \dagger$ & $<0.005 \dagger$ & $<0.005 \dagger$ \\
\hline
\end{tabular}

*Statistically not significant.

†Statistically significant compared with preinduction. 

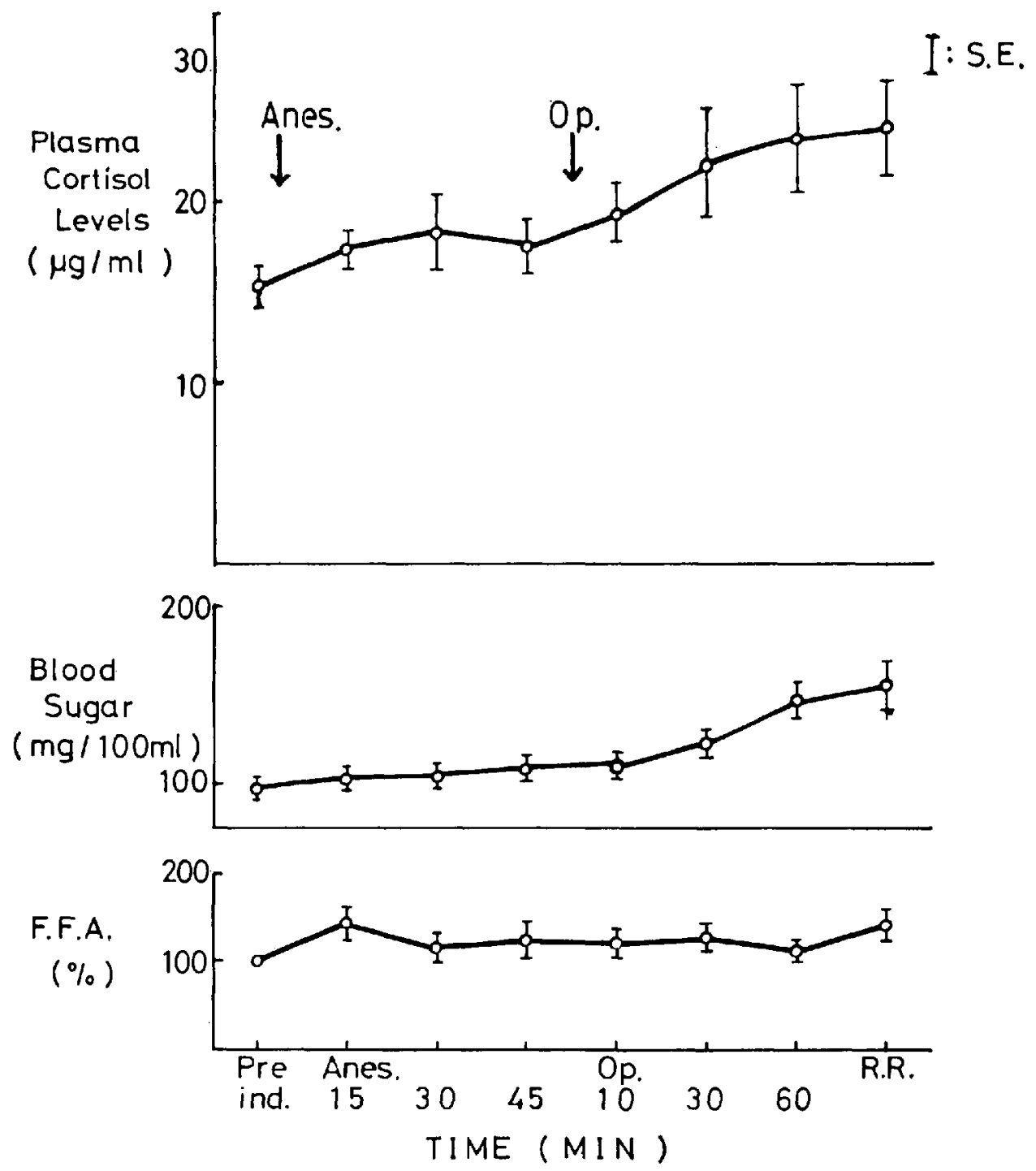

Figure 2. Plasma cortisol levels, blood sugar, and FFA during methoxyflurane anaesthesia and surgery.

15 minutes after induction in comparison with the control value. Plasma fFa levels slightly increased to $112 \pm 15$ per cent and $125 \pm 18$ per cent, 30 minutes and 45 minutes after induction of anaesthesia respectively. This tendency to increase continued during the operation, and it was $122 \pm 15$ per cent, $126 \pm 13$ per cent, and $115 \pm 11$ per cent, 10 minutes, 30 minutes and one hour respectively after the start of the operation; but these values were not statistically significant in comparison with the control level as shown in Table VI and Figure 2. FFA in plasma rose to the significant peak of $140 \pm 19$ per cent $(p<0.05)$ in the recovery room. 
TABLE VI

Plasma ffa Levels during Methoxyflurane Anaesthesia and Surgery (\%)

\begin{tabular}{|c|c|c|c|c|c|c|c|c|}
\hline \multirow[b]{2}{*}{ Subjects } & \multicolumn{8}{|c|}{ Time (min) } \\
\hline & preind. & anaes. 15 & 30 & 45 & op. 10 & 30 & 60 & recovery \\
\hline 1 & $100.0(16.6)^{*}$ & 238.0 & 65.4 & 85.9 & 116.6 & 123.9 & 106.8 & 121.5 \\
\hline 2 & $100.0(28.6)$ & 78.3 & 80.4 & 74.1 & 94.4 & 90.2 & 66.8 & 88.5 \\
\hline 3 & $100.0(12.6)$ & 82.5 & 97.6 & 100.0 & 143.7 & 100.0 & 119.8 & 100.0 \\
\hline 4 & $100.0(13.5)$ & 188.9 & 184.4 & 138.5 & 257.0 & 248.1 & - & 248.1 \\
\hline 5 & $100.0(33.5)$ & 280.6 & 297.9 & 203.6 & 264.2 & 206.3 & 142.0 & 114.6 \\
\hline 6 & $100.0(34.7)$ & 116.7 & 124.5 & 111.0 & 100.0 & 116.7 & - & 119.6 \\
\hline 7 & $100.0(51.3)$ & 58.5 & 39.0 & 45.8 & 46.8 & 98.2 & 121.6 & 86.2 \\
\hline 8 & $100.0(22.7)$ & 117.6 & 213.7 & 73.1 & 116.3 & 86.8 & 112.3 & 203.1 \\
\hline 9 & $100.0(85.4)$ & 41.0 & 19.1 & 52.9 & 13.0 & 55.0 & 32.4 & 73.4 \\
\hline 10 & $100.0(28.0)$ & 28.0 & 42.0 & 53.8 & 95.5 & - & 69.9 & 35.3 \\
\hline 11 & $100.0(24.0)$ & 138.3 & 156.3 & 101.3 & 90.8 & 181.7 & 181.7 & 184.2 \\
\hline 12 & $100.0(13.2)$ & 174.2 & - & 414.4 & 214.4 & 219.7 & 181.8 & 181.8 \\
\hline 13 & $100.0(35.6)$ & 96.6 & 71.6 & 86.2 & 91.6 & 91.6 & 102.8 & 132.0 \\
\hline 14 & $100.0(34.7)$ & 153.3 & 79.8 & 79.8 & 117.9 & 117.9 & 117.9 & 100.0 \\
\hline 15 & $100.0(26.7)$ & 149.4 & 111.6 & 161.0 & 123.2 & 172.7 & - & 172.7 \\
\hline 16 & $100.0(28.3)$ & 109.5 & 132.5 & 208.5 & 96.5 & 43.5 & 111.7 & 123.7 \\
\hline 17 & $100.0(58.1)$ & 122.7 & 100.0 & 82.4 & 37.0 & 75.0 & - & 75.0 \\
\hline 18 & $100.0(10.8)$ & 347.2 & 100.0 & 208.3 & 145.5 & 119.4 & 201.9 & 418.5 \\
\hline 19 & $100.0(29.5)$ & 219.7 & 89.5 & 91.5 & 156.3 & 127.1 & 63.4 & 84.4 \\
\hline 20 & $100.0(23.0)$ & 137.4 & 118.7 & 137.4 & - & 一 & 104.3 & 一 \\
\hline Mean & $100.0(30.7)$ & 143.9 & 111.8 & 125.5 & 122.1 & 126.3 & 114.8 & 140.1 \\
\hline S.E. & $(3.8)$ & 17.5 & 14.7 & 18.5 & 14.7 & 13.1 & 11.1 & 19.1 \\
\hline$p$ & & $<0.03 \dagger$ & n.s. $\ddagger$ & n.s.f & n.s. $\ddagger$ & n.s.f & n.s. $\ddagger$ & $<0.05 \dagger$ \\
\hline
\end{tabular}

*Actual value $(\mathrm{mg} / 100 \mathrm{ml})$.

†Statistically significant.

tStatistically not significant.

\section{Blood gases}

Arterial $\mathrm{pH}$ just prior to induction of anaesthesia was $7.48 \pm 0.02$; it varied from $7.43 \pm 0.05$ to $7.51 \pm 0.06$ during anaesthesia and surgery, and it was $7.41 \pm 0.03$ in the recovery room. Arterial $\mathrm{PCO}_{2}$ did not change appreciably from a preanaesthetic control value of $37.3 \pm 2.4 \mathrm{~mm} \mathrm{Hg}$, ranging from $32.0 \pm 3.6$ to $38.6 \pm 4.5 \mathrm{~mm} \mathrm{Hg}$ during anaesthesia and surgery. Arterial $\mathrm{Po}_{2}$ prior to induction of anaesthesia was $83 \pm 5 \mathrm{~mm} \mathrm{Hg}$. It varied from $181 \pm 21$ to $254 \mathrm{~mm} \mathrm{Hg}$ during anaesthesia and surgery. Arterial base excess changed from +6.8 to -4.0 . These analyses of blood gases indicate that there was no appreciable anoxia, $\mathrm{CO}_{2}$ retention or metabolic acidosis during the procedures.

\section{Discussion}

The present study demonstrates that premedication consisting of pentobarbital, meperidine, and atropine did not elevate plasma growth hormone level. However, methoxyflurane anaesthesia alone for 30 minutes significantly increased the blood level of growth hormone from a control value of $1.4 \pm 0.5 \mathrm{~m} \mu \mathrm{g}$ to $4.6 \pm 1.2$ $\mathrm{m} \mu \mathrm{g} / \mathrm{ml}$. Plasma growth hormone further increased and reached a peak value $(8.0 \pm 1.5 \mathrm{~m} \mu \mathrm{g} / \mathrm{ml})$ one hour after the start of surgery, confirming the reports of others. $^{7-11}$ It decreased in the postoperative period in the recovery room when the patient fully awoke, although it was still significantly higher than the control value. 
Schalch ${ }^{7}$ and Charters, ${ }^{10}$ who determined the response of plasma HGH to surgical stress, did not study the effect of anaesthesia alone. Therefore, they failed to evaluate the effect of individual anaesthetics precisely, and they reported that the degree of elevation in plasma HGH during surgery was approximately the same regardless of the type of anaesthetic agent used. There was considerable variability between subjects in the absolute elevation, which could not be correlated with the severity of the operation in our study. This finding confirms the report of Charters et al. ${ }^{10} \mathrm{We}$ also found that the depth of methoxyflurane anaesthesia itself had little influence on the plasma HGH levels.

Growth hormone increases protoplasm and causes positive total body balance of nitrogen, phosphorus, and potassium. It reflects largely an increased uptake of amino acids by many tissues, and enhances synthesis of amino acids. Second, growth hormone has diabetogenic and anti-insulin effects. It reduces peripheral utilization and uptake of glucose, decreases glucose tolerance, depresses glycolysis, and increases retention of glycogen. Third, growth hormone enhances mobilization of fatty acids from adipose tissue by stimulating dissolution of intracellular triglyceride, and increases FFA in blood. This lypolytic activity of $\mathbf{H G H}$ is blocked by insulin. Fourth, growth hormone causes translocation of potassium from plasma to muscle. Along with the retained nitrogen there is accretion of other constituents of tissues - sodium, potassium, and calcium. Thus, growth hormone in simplified expression appears to be an anabolic hormone and plays a protective role in the response of an organism to stress. ${ }^{5,6}$ Promotion of mobilization of fat (which prevents destruction of body protein), diminution in utilization of glucose (glucose sparing), and decrease in oxidation of amino acids (protein sparing) are favourable responses to stresses such as anaesthesia and surgery.

The mechanism of secretion of growth hormone is not clear at present. Factors stimulating secretion are many. Some of these are exercise, sleep, emotional stress, surgery, hypoglycaemia, insulin hypoglycaemia, and administration of $\beta$-adrenergic blockers.5,6 Factors depressing secretion of growth hormone are administration of glucose, corticosteroids and $\alpha$-adrenergic blockers. ${ }^{\sigma, 6}$ These factors influence the secretion of hypothalamic growth hormone releasing factor (GRF), through which secretion of growth hormone from anterior pituitary gland is stimulated. It is known that a plasma HGH peak (13-72 $\mathrm{m} \mu \mathrm{g} / \mathrm{ml}$ ) lasting 1.5-3.5 hours appears with the onset of deep nocturnal sleep in man. Smaller HGH peaks occasionally appear during subsequent deep sleep phases, and peak HGH secretion is not correlated with change in plasma glucose, insulin, and cortisol. ${ }^{16,17}$ Therefore, the present authors speculate that there is a possibility that methoxyflurane anaesthesia evokes a rise in secretion of HGH through stimulation of hypothalamic $\mathrm{GRF}$, as natural sleep does.

Plasma insulin levels during methoxyflurane anaesthesia and surgery ranged around $20 \mu \mathrm{v} / \mathrm{ml}$ but tended to decrease insignificantly. There was a postoperative rise in insulin levels. While blood glucose was not increased during methoxyflurane anaesthesia alone, it was elevated during surgery. A similar finding in the dog was reported by Dobkin. ${ }^{18}$ It is well known that surgical stress elevates blood glucose by increasing glycolysis and glyconeogenesis. ${ }^{2}$

Response of blood glucose to HGH and insulin appears to be different in unstressful states and stressful conditions such as anaesthesia and surgery. Administra- 
tion of glucose under normal conditions elevates blood insulin level acutely; on the other hand blood HGH concentration is decreased at first, then it rises three to four hours later. However, during operation the elevated blood glucose neither increased the plasma insulin level nor significantly decreased the plasma $\mathbf{H G H}$ level. Glick et al. ${ }^{19}$ also observed that the plasma HGH level was not influenced by glucose infusion during operation. Epinephrine is known to depress insulin secretion as a response to hyperglycemia. ${ }^{5,6}$

Plasma FFA increased slightly during induction of methoxyflurane anaesthesia and in the recovery room. Otherwise it did not change markedly. Plasma FFA is usually elevated by increased secretion of $\mathbf{H G H}$, corticosteroids, and epinephrine. Epinephrine mobilizes fatty acids, but tends to depress blood FFA elevation by hyperglycaemia. Cortisol also affects fat mobilization and the production of hyperglycaemia, thereby tending to decrease blood FFA levels. ${ }^{5,6}$ These complicated mechanisms influence blood FFA, but as our results show, no appreciable variation was observed during anaesthesia or surgery.

HGH and adrenocorticosteroids of the glucocorticoid type are insulin antagonists $^{5,8}$ which decrease glucose utilization and increase the mobilization of fat. It is postulated that a possible hormonal interaction including $\mathbf{H G H}$, cortisol, insulin, and catecholamines may occur. They might play one of the important roles in carbohydrate and fat metabolism during anaesthesia and surgery. Therefore, the alterations in carbohydrate and fat metabolism during anaesthesia and surgery cannot be explained by simple sympatho-adrenal activity.

Plasma cortisol level did not change markedly during methoxyflurane anaesthesia alone, but it increased stepwise during surgery and in the postoperative period, which confirmed our previous observations. ${ }^{20}$ It is interesting to note that the rising curves for HGH and cortisol in plasma are quite different. The HGH level reached a peak one hour after the start of surgery and decreased later. However, the cortisol level in plasma rose stepwise, and its highest concentration appeared in the postoperative period.

\section{SUMmary AND Conclusion}

The present study was undertaken to investigate the effects in 20 patients of methoxyflurane anaesthesia alone on carbohydrate and fat metabolism by determining plasma growth hormone (HGH), insulin, blood glucose, free fatty acids (FFA), and cortisol, and to compare these with the effects of anaesthesia plus surgery. Analysis of plasma growth hormone and insulin levels was made by radioimmunoassay utilizing $I^{125}$ labelled hormones.

Determinations of plasma $\mathbf{H G H}$, insulin, cortisol, FFA, and blood glucose were made simultaneously before induction of methoxyflurane anaesthesia, 15, 30, and 45 minutes after induction of anaesthesia, 5-10, 30, and 60 minutes after the start of surgery, and in the postoperative period when the patient was adequately awake in the recovery room.

Plasma HGH levels during methoxyflurane anaesthesia alone significantly increased for 45 minutes from a control level of $1.4 \pm 0.5 \mathrm{~m} \mu \mathrm{g} / \mathrm{ml}$ to $6.0 \pm 1.6$ $\mathrm{m} \mu \mathrm{g} / \mathrm{ml}$. They further increased and reached a peak $(8.0 \pm 1.5 \mathrm{~m} \mu \mathrm{g} / \mathrm{ml})$ one 
hour after the start of operation. Plasma insulin levels did not change appreciably during anaesthesia or surgery.

Blood glucose levels did not alter markedly but increased gradually during surgery. Plasma FFA levels did not change markedly during the entire course of anaesthesia or surgery. Plasma cortisol levels increased stepwise and significantly during surgery. The pattern of elevation in plasma HGH was different from that of plasma cortisol.

\section{RÉSUMÉ}

Cette étude a été entreprise chez 20 malades, pour dépister les effets de l'anesthésie au méthoxyflurane seule sur le métabolisme des hydrates de carbone et des graisses en recherchant dans le plasma l'augmentation des hormones (HGH), de l'insuline, de la glycémie, des acides gras libres (FFA) du cortisol et ensuite, pour comparer ces effets avec ceux de l'anesthésie et de la chirurgie ensemble. L'analyse de l'augmentation plasmatique des taux d'hormones et d'insuline a été faite en employant des hormones marquées à l' $1^{185}$.

La détermination des HGH, de l'insuline, du cortisol, des FFA et de la glycemie a été faite, en même temps, avant l'intubation de l'anesthésie au méthoxyflurane et 15,30 et 45 minutes après l'induction de l'anesthésie; puis, de 5 à 10, 30 et 60 minutes après le début de la chirurgie et, au cours des suites opératoires, lorsque le malade était suffisamment réveillé dans la salle de réveil.

Au cours de lanesthésie au méthoxyflurane seulement, le taux du HGH plasmatique au cours des 45 premières minutes, a augmenté de façon significative du taux de contrôle de $1.4 \pm 0.5 \mathrm{~m} \mu \mathrm{g} / \mathrm{ml}$ à $6.0 \pm 1.6 \mathrm{~m} \mu \mathrm{g} / \mathrm{ml}$. Une heure après le début de l'opération, il a augmenté encore et a touché un sommet $(8.0 \pm 1.5$ $\mathrm{m} \mu \mathrm{g} / \mathrm{ml}$. Les taux d'insuline plasmatique ne se sont pas modifiés de façon appréciable durant l'anesthésie et la chirurgie.

La glycémie n'a pas varié beaucoup, mais, graduellement, au cours de la chirurgie, elle a augmenté. Les taux de FFA plasmatiques n'ont pas changé beaucoup durant toute l'expérience: anesthésie et chirurgie. Au cours de la chirurgie, le taux de cortisol plasmatique a augmenté en flèche et de façon importante. La courbe d'élévation du cortisol et des HGH plasmatiques ne se ressemblait pas.

\section{REFERENCES}

1. Drucker, W. R.; Costley, C.; Stults, R.; Holden, W. D.; Craig, J.; Miller, M.; Hofmans, N.; \& Woodward, H. Studies of Carbohydrate Metabolism during Ether Anesthesia: Effect of Ether on Glucose and Fructose Metabolism. Metabolism. 8: 827 (1959).

2. Bunker, J. P. Neuroendocrine and Other Effects on Carbohydrate Metabolism during Anesthesia. Anesthesiology. 24: 515 (1963).

3. Henneman, D. H. \& Vandam, L. D. The Metabolic Consequences of Epinephrine and Insulin Administered during Ether Anesthesia in Man. Anesthesiology, 19: 104 (1958).

4. Greene, N. M. Inhalation Anesthetics and Carbohydrate Metabolism. Baltimore: Williams \& Wilkins (1963).

5. Knomil, E. \& Hotchiss, J. Growth Hormone, Ann. Rev. Physiol. 26: 47 (1964).

6. Matsuzaki, F. \& Raben, M. S. Growth Hormone. Ann. Rev. Pharm. 5: 137 (1965).

7. Schalch, D. S. The Influence of Physical Stress and Exercise on GH and Insulin Secretion in Man. J. Lab. Clin. Med. 69: 256 (1967). 
8. Glick, S. M.; Roth, J.; Yalow, R. S.; \& Berson, S. A. The Regulation of Growth Hormone Secretion. Rec. Prog. Hormone Res. 24: 241 (1965).

9. Ross, H.; Johnstone, I. D. A.; Welbon, T. A.; \& Wrught, A. D. Effect of Abdominal Operation on Glucose Tolerance and Serum Levels of Insulin, GH, and Hydrocortisone. Lancet. $i i$ : 563 (1966).

10. Charters, A. C.; Odell, W. D.; \& Thompson, J. C. Anterior Pituitary Function during Surgical Stress and Convalescence: Radioimmunoassay Measurements of Blood TSH, LH, FSH, and Growth Hormone. J. Clin Endocr. 29: 63 (1969).

11. Ketteren, H.; Powell, D.; \& Unger, R. H. Growth Hormone Response to Surgical Stress. Clin. Res. 14: 65 (1966).

12. Morgan, C. R. \& Lazarow, A. Immunoassay of Insulin: Two Antibody System. Diabetes. 12: 115 (1963).

13. Murphy, B. E. P. Some Studies of the Protein-Binding of Steroid and Their Application to the Routine Micro and Ultra Micro Measurement of Various Steroids in the Body Fluids by Competition Protein-Binding Radioassay. J. Clin. Endocrin. 27: 973 (1967).

14. Somogyi, M. Notes on Sugar Determination. J. Biol. Chem. 195: 19 (1952).

15. Dumcombe, W. G. The Colorimetric Microdetermination of Longchain Fatty Acids. Biochem. J. 88: 7 (1963).

16. Takahashi, Y.; Kupnis, D. M.; \& Daughaday, W. H. Growth Hormone Secretion during Sleep. J. Clin. Invest. 47: 2079 (1968).

17. Honda, Y.; Takahasho, K.; Takahashi, S.; Azuma, K.; Irue, M.; Sakuma, M.; Tsushima, T.; \& SHzume, K. Growth Hormone Secretion during Nocturnal Sleep in Normal Subjects. J. Clin. Endocr. 29: 20 (1969).

18. Dobkin, A. B. \& Fedorux, S. Comparison of the Cardiovascular Respiratory and Metabolic Effects of Methoxyllurane and Halothane in Dogs. Anesthesiology. 22: 355 (1961).

19. Glick, S. M.; Roth, J.; Yalow, R. S.; \& Berson, S. A. The Regulation of Growth Hormone Secretion. Rec. Prog. Hormone Res. 24: 241 (1965).

20. Oyama, T.; Shibata, S.; Matsumoto, F.; Matsukt, A.; Kmutra, K.; Takazawa, T.; \& Kudo, T. Adrenocortical Function Related to Methoxyflurane Anaesthesia and Surgery in Man. Canad. Anaes. Soc. J. 15: 362 (1968). 